\title{
PENGEMBANGAN MEDIA CARTOON STRIPS DALAM PEMBELAJARAN BAHASA INGGRIS DI SMK
}

\author{
Elly Syahadati ${ }^{1}$, Desi Sri Asturi ${ }^{2}$, Ageung Darajat $^{3}$ \\ 1,2,3Pendidikan Bahasa Inggris \\ Fakultas Bahasa dan Seni IKIP PGRI Pontianak \\ Corresponding Email: syahadati1979@gmail.com
}

Received: 10th of December 2019, Accepted: $4^{\text {th }}$ of March 2020, Published: $22^{\text {th }}$ of December 2020

\begin{abstract}
Abstrak
Tujuan dari penelitian ini adalah untuk menjelaskan pengembangan kosakata Bahasa Inggris dan kualitas penggunaan cartoon strips sebagai media dalam pembelajaran Bahasa Inggris. Penelitian adalah penelitian RnD (Penelitian dan Pengembangan). Sebanyak 37 siswa kelas X SMKN 1 Sanggau sebagai subyek penelitian ini. Penelitian pengembangan ini mengikuti tujuh langkah penelitian, meliputi : 1) penelitian dan pengumpulan data, 2) perencanaan, 3) pengembangan produk awal, 4) uji coba awal, 5) revisi desain, 6) uji coba lapangan, dan 7) revisi dan penyempurnaan produk. Hasil analisis kebutuhan mengungkapkan bahwa subjek membutuhkan media yang nyata dengan warna yang menarik. Temuan lainya menunjukkan bahwa produk media pembelajaran bahasa Inggris berupa cartoon strips layak digunakan bagi siswa SMK. Dapat disimpulkan bahwa cartoon strips dapat diaplikasikan sebagai media dalam proses pembelajaran di kelas
\end{abstract}

Kata kunci: cartoon strips, kosakata bahasa Inggris, SMK, Penelitian dan Pengembangan

\begin{abstract}
The purpose of this research was to describe the development of English vocabulary and the quality of cartoon strips for media in English teaching learning process. This research was a Research and Development (RnD). The subjects were 37 students in the $\mathrm{X}$ grade state of SMKN 1 Sanggau. This research development followed seven steps including: 1) researching and collecting data, 2) planning, 3) initial product development,4) initial trial, 5) revision, 6) field trial, 7) revision and completion of product. Based on need analysis, students need colorfull and interesting media. Therefore, it could be concluded that cartoon strips was applicable as a media in English teaching learning process in the classroom.
\end{abstract}

Keywords: Cartoon Strips, English Vocabulary, SMK, Research and Development

Copyright @ 2020 Elly Syahadati, Desi Sri Asturi, Ageung Darajat

\section{PENDAHULUAN}

SMK merupakan lembaga atau institusi pendidikan menengah yang mempersiapkan siswa untuk bekerja dalam bidang keahlian tertentu. Pengembangan media pembelajaran sangat diperlukan di lingkup SMK, karena banyak kendala yang dihadapi oleh guru mata pelajaran adaptif, normatif maupun produktif dalam menyampaikan materi pelajaran kepada siswa. Kemampuan berbahasa Inggris harus dikuasai oleh seluruh siswa, dengan adanya keadaan yang demikian, maka diperlukan kerja keras guru mata pelajaran bahasa Inggris untuk dapat meningkatkan hasil belajar bahasa Inggris seperti yang diharapkan. 
Berbagai upaya dan strategi dilakukan guru supaya bahan atau materi pelajaran tersebut dapat dengan mudah dicerna oleh subjek belajar. Salah satu strategi yang dapat dilakukan olah guru yaitu dengan menggunakan media pembelajaran. Al-Tabany (2014: 23) mengatakan bahwa media pembelajaran dapat didefinisikan sebagai kerangka konseptual yang melukiskan prosedur dalam mengorganisasikan pengalaman belajar untuk belajar mencapai tujuan belajar.

Rendahnya penguasaan kosakata siswa dalam bahasa Inggris secara umum dipengaruhi oleh berbagai faktor antara lain: (1) minimnya pengetahuan siswa; (2) rendahnya kemauan siswa terhadap bacaan terutama bacaan dalam bahasa Inggris; dan (3) kurangnya media dalam pengajaran kosakata. Di SMKN 1 Sanggau, khusus kelas X, kemampuan penguasaan kosakata bahasa Inggris siswanya masih rendah.Hal ini dapat dilihat dari nilai hasil ulangan harian siswa yang masih rendah serta tes lisan oleh guru dalam proses belajar mengajar di kelas. Dari 37 siswa hanya 12 siswa atau $36,36 \%$ saja yang memperoleh nilai lebih dari atau sama dengan KKM yaitu 65 , sisanya $63,64 \%$ masih belum tuntas.

Pengembangan media pembelajaran Cartoon Strip diharapkan menjadi solusi yang tepat untuk mengatasi masalah-masalah pembelajaran bahasa Inggris yang ada sekarang. Istilah cartoon strips pertama kali dikenal di Inggris, cartoon yang berasal dari cartone, yang berarti karton/ kertas tebal. Saat itu karton digunakan untuk membuat sketsa lukisan istana yang banyak berisi sindiran terselubung terhadap pejabat istana. Kemudian muncul istilah cartoon strips untuk menyebut karton yang dibuat dalam beberapa panel/ bingkai bergambar. Dapat disimpulkan bahwa cartoon strips adalah media bergambar yang berbentuk lembaranlembaran bingkai/kolom-kolom yang berisi teks percakapan (Kurnia, 2008).

\section{METODE}

Penelitian ini merupakan penelitian pengembangan (Research and Development) dengan fokus mengembangkan materi bahasa Inggris agar menjadi lebih praktis dan lebih menarik untuk diikuti bagi siswa. Mack, Natasha et al. (2005: 1) mengatakan penelitian kualitatif adalah jenis penelitian ilmiah. Penelitian ini dilaksanakan di SMKN 1 Sanggau Jalan Sudirman Kabupaten Sanggau Kalimantan Barat. Penelitian dilaksanakan pada semester genap Tahun Akademik 2018/2019. Subjek penelitian adalah siswa kelas X SMKN 1 Sanggau. Sebanyak 37 Siswa sebagai sumber data dapat memberikan data berupa penggunaan media pembelajaran oleh siswa. Sumber data tersebut bertujuan untuk mengetahui frekuensi penggunaan media pembelajaran pada pelajaran bahasa Inggris, ketertarikan, dan kebutuhan siswa untuk menggunakan media pembelajaran pada saat pelajaran Bahasa Inggris. Sumber data yang digunakan dalam penelitian ini berasal dari hasil penyebaran angket. 
Penelitian dan pengembangan yang dilakukan adalah upaya untuk mengembangkan produk media cartoon strips sebagai media pembelajaran bahasa Inggris untuk siswa kelas $\mathrm{X}$ SMKN 1 Sanggau. Upaya pengembangan media tersebut terdiri dari tujuh tahap yang telah diadaptasi dan disesuaikan dengan kebutuhan. Langkah pertama adalah penelitian dan pengumpulan data. Langkah pertama tersebut melaksanakan pengukuran kebutuhan dengan menggunakan teknik wawancara. Wawancara ditujukan kepada guru Bahasa Inggris kelas X SMKN 1 Sanggau.

Langkah kedua adalah perencanaan produk awal. Pada langkah tersebut akan dijelaskan berkaitan dengan rancangan produk yang berupa rancang bidang dari media cartoon strips bahasa Inggris dan proses pengembangan produk. Proses pengembangan menjelaskan tentang langkah-langkah pengembangan media cartoon strips bahasa Inggris. Langkah ketiga adalah pengembangan produk awal. Pengembangan produk diawali dengan pengembangan bahan pembelajaran, meliputi menganalisis standar kompetensi dan kompetensi dasar, penentuan kompetensi dengan merumuskan indikator yang dikembangkan dalam sebuah rencana pelaksanaan pembelajaran (RPP).

Langkah keempat adalah instrumen evaluasi. Evaluasi bertujuan untuk mengetahui kelayakan dan kualitas dari produk yang dikembangkan. Instrumen evaluasi berupa angket penilaian yang ditujukan kepada expert judgement. Expert judgement memvalidasi dengan memberi skor dan saranyang menjadi acuan pada revisi desain produk awal. Langkah kelima adalah uji coba terbatas. Uji coba terbatas dilaksanakan pada kelompok terbatas. Pada langkah ini dilaksanakan uji coba penggunaan media pada kelompok terbatas, kemudian subjek penelitian mengisi angket umpan balik. Angket tersebut bertujuan untuk menilai produk yang telah dikembangkan. Kemudian, dilaksanakan revisi produk. Setelah mendapat penilaian pada kelompok terbatas, kemudian produk direvisi sesuai dengan masukan, kritikan, dan saran. Revisi dilakukan untuk memperbaiki kekurangan dari produk. Langkah keenam adalah uji coba lapangan. Uji coba lapangan dilakukan di kelompok besar. Pengujian dilakukan dengan tujuan untuk mendapatkan informasi dan penilaian berkaitan dengan efektivitas produk yang sudah divalidasi dan direvisi. Langkah ketujuh adalah revisi dan penyempurnaan produk. Menyempurnakan produk berdasarkan hasil uji coba lapangan. Penyempurnaan produk memperhatikan hasil angket umpan balik kelompok besar pada uji coba lapangan.

Teknik yang digunakan dalam penelitian ini adalah teknik obervasi atau pengamatan. Pengukuran yang dilakukan adalah untuk melihat keterampilan proses pengajaran bahasa Inggrisdengan menggunakan media cartoon strips. Instrumen pembelajaran yang akan 
digunakan dalam penelitian ini adalah dengan teknik wawancara dan angket. Kualitas pengumpulan data mempengaruhi kualitas instrumen penelitian, yaitu validitas dan reliabilitas. Observasi (observation) atau pengamatan merupakan suatu teknik atau cara pengambilan data dengan jalan mengadakan pengamatan terhadap kegiatan yang sedang berlangsung.

Data yang diperoleh dalam penelitian dan pengembangan ini adalah data kualitatf dan kuantitatif. Data kualitatif berupa informasi yang didapat dari validasi oleh expert judgement, observasi kegiatan siswa di kelas, kegiatantan wawancara dengan guru bahasa Inggris, dan angket yang ditujukan kepada siswa kelas X SMKN 1 Sanggau. Hasil validasi merupakan data yang digunakan sebagai pedoman untuk merevisi produk dan mengetahui kelayakan produk yang akan diujicobakan.

\section{HASIL DAN PEMBAHASAN}

\section{Data Analisis Kebutuhan}

Analisis kebutuhan bertujuan untuk mengukur kebutuhan terhadap penggunaan media pembelajaran pada mata pelajaran bahasa Inggris siswa SMK. Data analisis kebutuhan menggunakan metode wawancara dengan guru kelas. Proses pembelajaran di SMKN 1 Sanggau sama halnya seperti proses pembelajaran pada umumnya, yaitu adanya apersepsi, elaborasi. Guru selalu merancang strategi pembelajaran yang tepat untuk para siswa. Alokasi waktu mengajar bahasa Inggris di kelas X, yaitu 1 minggu 2 kali pertemuan dan tiap pertemuan alokasi waktunya, yaitu 2 x 45 menit.

Metode pembelajaran yang sering digunakan di dalam kelas adalah metode diskusi dan metode ceramah. Metode diskusi bertujuan untuk menciptakan interaksi antara guru dengan siswa, sehingga para siswa terbiasa untuk tidak merasa takut ketika mengungkapkan pendapat. Media pembelajaran yang bersifat visual akan semakin mempermudah siswa menangkap materi pembelajaran. Selama proses pembelajaran bahasa Inggris, hambatan yang sering muncul adalah kesulitan menyusun kalimat. Siswa kelas X sering melakukan kesalahan dalam menyusun sebuah kalimat yang sesuai dengan kaidah yang benar. Maka dari itu, untuk mengatasi hambatan tersebut mereka harus sering dibiasakan untuk membuat sebuah kalimat seperti kalimat tanya, kalimat berita, kalimat langsung dan tak langsung, bahkan mengarang. Pernyataan di atas menunjukkan bahwa para siswa kelas X memiliki kesulitan dalam menyusun kalimat yang baik dan benar. Guru Bahasa Inggris mengungkapkan bahwa mereka selalu salah menempatkan kata yang berfungsi sebagai subyek dan obyek. Usaha untuk membiasakan mereka menulis cukup membantu terutama untuk mengidentifikasi kesulitan mereka secara individu. 
Media pembelajaran yang digunakan untuk menunjang materi bahasa Inggris adalah koran, majalah, novel, buku ilmu pengetahuan, dan internet. Keberagaman media tersebut harus selalu ditunjukkan secara langsung kepada siswa, sehingga mereka lebih mampu memahami dan mengerti tentang materi yang diajarkan. Media gambar adalah media yang sering digunakan. Media gambar memiliki karakteristik menarik karena menggunakan warnawarna yang menarik dan sederhana.

Media pembelajaran yang sering digunakan adalah media gambar. Media gambar memang sederhana, mudah digunakan, terjangkau, dan memiliki warna-warna yang menarik. Oleh karena itu, media gambar sering digunakan. Selain itu, guru juga dituntut untuk selalu menggunakan media pembelajaran pada setiap pembelajaran di kelas. Media pembelajaran yang cocok bagi siswa kelas $\mathrm{X}$ adalah media pembelajaran yang memiliki warna yang menarik dan harus benda riil/nyata. Kemenarikan sebuah media pembelajaran akan membuat mereka penasaran dan timbul keinginan menggunakan media pembelajaran tersebut. Dalam penelitian ini, peneliti mencoba untuk menerapkan media pembelajaran cartoon stips bagi siswa kelas $\mathrm{X}$ SMKN 1 Sanggau.

\section{SIMPULAN}

Berdasarkan penelitian yang telah dilakukan, maka dapat ditarik kesimpulan bahwa media cartoon strips sangat membantu dan layak digunakan dalam pembelajaran bahasa Inggris terutama dalam memperkaya kosakata bahasa Inggris siswa kelas X SMKN 1 Sanggau. Berdasarkan Hasil tabel rekapitulasi menunjukkan hasil secara keseluruhan tentang penilaian terhadap kualitas media pembelajaran cartoon strips bahasa Inggris yang telah dikembangkan, media pembelajaran cartoon strips bahasa Inggris mendapatkan rata-rata skor 3,75 dengan kriteria "Sangat Baik".

Adapun saran-saran yang dapat dipertimbangkan dalam pengembangan cartoon strips bahasa Inggris sehingga jika ada penelitian dan pengembangan media seperti cartoon strips bahasa Inggris dan atau media konvensional lainnya dapatmenghasilkan produk yang lebih baik.

\section{UCAPAN TERIMA KASIH}

Peneliti banyak menerima bantuan dalam melaksanakan dan menyelesaikan penelitian ini. Oleh karena itu, pada kesempatan ini peneliti mengucapkan terima kasih kepada semua pihak yang telah membantu terutama kepada IKIP PGRI Pontianak dan Lembaga Penelitian dan Pengabdian pada Masyarakat IKIP PGRI Pontianak atas pengelolaan administrasi yang baik bagi proyek penelitian ini. Pihak sekolah yang banyak membantu sehingga penelitian dapat dilaksanakan. 
Elly Syahadati, Desi Sri Asturi, Ageung Darajat

\section{REFERENSI}

Al-Tabany, TIB. 2014. MendesainMedia Pembelajaran Inovatif, Progresif dan Kontekstual. Jakarta: Pranadamedia.

Aqib, Zainal. 2003. Profesional Guru dalam Pembelajaran. Surabaya: Insan Cendekia.

Hamalik, O. 2008. Proses Belajar Mengajar. Jakarta: Bumi Aksara.

Komalasari, Kokom. 2010. Pembelajaran Kontekstual Konsep dan Aplikasi.Bandung: Refika Aditama.

Mack, N. et al. 2005. Qualitative Research Methods: A Data Collector's Field Gide. Available at (http://www.fhi.org, diakses 20 Januari 2016.

Uno, Hamzah. 2008. Orientasi Baru dalam Psikologi Pembelajaran. Jakarta: Bumi Aksara.

Wijana, Eka. 2011. Penerapan Media Belajar Word Square untuk Meningkatkan Hasil Belajar Siswa Pada Pembelajaran Matematika (Penelitian Tindakan Kelas Siswa VIII-C SMP Al-Falah Karangwangi Depok). Cirebon: IAIN. 